\author{
EWA ROGOWSKA-CYBULSKA \\ Uniwersytet Gdański
}

\title{
O ELEMENTACH WIEDZY NAUKOWEJ W ETYMOLOGIACH LUDOWYCH (NIENAUKOWYCH) NAZW POLSKICH MIEJSCOWOŚCI
}

Zjawisko językowe, definiowane jako 'błędne z naukowego punktu widzenia objaśnienie pochodzenia jakiegoś wyrazu, oparte na podobieństwie jego formy do innych wyrazów lub na innych swobodnych skojarzeniach' (WSJP) ${ }^{1}$, nosi w polskim językoznawstwie różne nazwy, m.in. etymologii asocjacyjnej, dyletanckiej, fantazyjnej, folklorystycznej, naiwnej, nienaukowej, potocznej i synchronicznej, bywa też określane mianem pseudoetymologii i reinterpretacji etymologicznej ${ }^{2}$, najczęściej jednak używa się w tym znaczeniu wyrażenia etymologia ludowa. Ten nie tylko najpopularniejszy, ale i najstarszy termin używany dla nazwania objaśniania pochodzenia wyrazów niezgodnego z wiedzą językoznawczą „ttumaczy się częstością i wielką skalą tego zjawiska wśród mas ludowych" (Kania, Tokarski 1984: 152). Nie odzwierciedla on jednak istoty fenomenu językowego, do którego się odnosi, bowiem - jak zauważa Halina Karaś w opracowaniu poświęconym gwarom ludowym - „przykłady etymologii ludowej występują nie tylko w gwarach, choć tu są najczęstsze, ale także w języku ogólnym" (Karaś). Nie jest też słuszny sąd, jakoby etymologia ludowa była „pomyłką typową dla ludzi słabo wykształconych, którzy przypisują wyrazom fantastyczne pochodzenia i formację" (Guiraud 1976: 70). Jak bowiem piszą Anna Paluszak-Bronka i Magdalena Czachorowska, „etymologizowanie jest właściwością umysłu ludzkiego" (Paluszak-Bronka, Czachorowska 1998: 410). Stanisław Kania i Jan Tokarski dodają, że „potrzeba etymologizowania jest tak żywa i powszechna, że skłonni jesteśmy ulegać jej wszyscy bez względu na stopień wykształcenia, i często się zdarza, że z braku właściwych danych idziemy za pierwszym lepszym pomysłem, przypisując wyrazom fantastyczne, nieprawdopodobne źródłosłowy, tworząc bajeczki etymologiczne" (Kania, Tokarski 1984: 152).

Mimo że etymologia ludowa stanowi „zapis potocznej świadomości językowej, świadomości rządzącej się innymi celami i zasadami niż myślenie naukowe" (Brzozowska 2009: 120), możemy w niej niekiedy zauważyć elementy wiedzy naukowej. W szczególności wśród licznych przykładów etymologii ludowych nazw polskich miejscowości znajdziemy

\footnotetext{
1 Są to definicje hasel: etymologia ludowa, potoczna etymologia w WSJP.

2 O etymologii ludowej pisali m.in.: Cienkowski 1972; Michow 2008; Zierhofferowa, Zierhoffer 2012.
} 
również takie „błędne, sprzeczne z dokumentacją językoznawczą wyjaśnieni[a] pochodzenia określonego wyrazu [...]" (Kostkiewiczowa 1988: 132), które powstały w wyraźnym związku z naukową wiedzą o świecie i języku. Przy czym nie chodzi tu o wpływ nauki na językowy obraz świata, czyli o ,zasadnicz[ą] wątpliwość co do kształtu owego językowego obrazu świata współcześnie, kiedy potoczny sposób postrzegania przeciętnego użytkownika języka miesza się z elementami wiedzy naukowej zdobytej podczas edukacji oraz wiedzy kulturowej czerpanej z przekazów medialnych" (Czelakowska 2017: 20-21), lecz o celowe sięganie przez twórców etymologii nienaukowych do tekstów naukowych.

Celem niniejszego artykułu jest opisanie podstawowych rodzajów tego typu pseudoetymologii. W zgromadzonym przeze mnie materiale przykładowym obejmującym około tysiąca etymologii asocjacyjnych polskich nazw miejscowych, wyekscerpowanych z różnorodnych tekstów drukowanych i internetowych, z ankiet pisemnych i z wywiadów ustnych, można wyróżnić trzy typy etymologii nienaukowych posługujących się elementami wiedzy naukowej.

\section{Zniekształcone etymologie naukowe}

Najsilniejszy związek między etymologiami nienaukowymi i naukowymi nazw miast, miasteczek, osad i wsi występuje w wypadku zniekształcenia przez niespecjalistów etymologii onomastycznych, popularyzowanych zazwyczaj przez szkołę i internet. Użytkownicy języka polskiego niemający przygotowania językoznawczego, przyswajając etymologię nazwy swojej miejscowości, niekiedy zmieniają w niej pewne szczegóły tak znacznie, że czyni to ją niezgodną z wersją pierwotną, w związku z czym nowo powstałe objaśnienie nabiera cech etymologii nienaukowej.

Tak stało się m.in. w wypadku jednej z pseudoetymologii toponimu Modzele (pow. łomżyński, woj. podlaskie) stanowiącego pierwszy człon nazwy wsi Stare Modzele. Jest to w świetle badań historii osadnictwa nazwa ponowiona, nadana tej wsi przez pierwszych mieszkańców ze względu na nazwę wsi Modzele 3 pod Nasielskiem, wcześniej przez nich zamieszkiwanej: „,w 1402 r. książę Janusz I nadał w lesie Sokolałąka 20 włók Mikołajowi z Modzeli w ziemi ciechanowskiej oraz 10 włók Ściborowi. Powstały tu wsie Modzele Stare, Modzele-Skudosze i Modzele-Wypychy" (NMP 209: VII, 209). Nazwę Modzele nadano wsi w Łomżyńskiem zapewne tym chętniej, że pierwszy osadnik na nowym terenie, Mikołaj z Modzeli, nosił przydomek Modzel (Brodzicki 1999: 96). Według jednej z osób biorących udział w ankiecie dotyczącej pochodzenia nazwy ich rodzinnej miejscowości nazwa miejscowa Modzele jest wprawdzie motywowana antroponimem $\mathrm{Modzel}^{4}$, ale inne

\footnotetext{
${ }^{3}$ Natomiast toponim Modzele odnoszący się do wsi w ziemi ciechanowskiej jest nazwą rodową powstałą od antroponimu i nazwy herbowej Modzel, motywowanych rzeczownikiem apelatywnym modzel 'nagniotek' (NMP 209: VII, 209).

${ }^{4}$ Etymologia nienaukowa różni się w tym wypadku od naukowej tylko innym odniesieniem nazwy własnej wybranej na wtórny wyraz podstawowy. Taki typ etymologii nienaukowych nie należy jednak do wyjątków wśród pseudoetymologii polskich toponimów, a jeszcze częstsze są etymologie potoczne, które wywodzą reetymologizowany toponim od tego samego wyrazu apelatywnego co etymologia naukowa, różniąc się od etymologii naukowej jedynie wykładnią semantyczną, por. Rogowska-Cybulska 2013).
} 
jest jego odniesienie ${ }^{5}$ : według informatora nosiciel tego (proto)nazwiska miał na imię nie Mikołaj, ale Janusz, por.: „Miejscowość tą [tak!] założył bodajże Janusz Modzel, około 600 lat temu. Nazwa pochodzi więc od jego nazwiska" (Ankieta 2).

Młody mieszkaniec Modzeli pomylił zapewne Mikołaja Modzela z księciem Januszem I, który również brał udział w założeniu wsi, ale jako nadawca ziemi. Uczeń musiał zatem wcześniej poznać etymologię naukową Modzeli, co było tym łatwiejsze, że można ją znaleźć również na stronach internetowych, m.in. w popularnej Wikipedii' ${ }^{6}$.

Inny przykład etymologii skojarzeniowej, która powstała pod wpływem lektury etymologii onomastycznej, stanowi jedna z pseudoetymologii toponimu Łomża (woj. podlaskie), a źródłem pomyłki było w tym wypadku niezrozumienie objaśnień etymologicznych autorstwa Karola Zierhoffera, zamieszczonych m.in. w Nazwach miejscowych pótnocnego Mazowsza i wielokrotnie powielanych, m.in. w Internecie, por.:

Nazwa ta jest urobiona za pomocą przyrostka $-\dot{z} a\left(<*_{-}\right.$๖gja) od tego samego rdzenia, co stpol. łomić 'łamać'. Oznaczała ona przypuszczalnie 'miejsce, gdzie był jakiś łom', tzn. jakieś pokruszone bloki kamienne względnie połamane przez wiatr drzewa. Jest to zatem nazwa topograficzna (Zierhoffer 1957: 247).

Tymczasem jeden z młodych łomżan pochodzenie nazwy rodzinnego miasta tłumaczy następująco: „Od łoma, bo powstała na gruzach” (Ankieta 1).

Ankietowany uczeń użytemu przez Karola Zierhoffera wyrażeniu pokruszone bloki kamienne nadał zatem znaczenie 'gruzy', zapewne dlatego, że rzeczownikowi blok przypisał sens 'wielopiętrowy budynek mieszkalny o formie zbliżonej do prostopadłościanu (WSJP). Nie zmieniając wyrazu podstawowego reetymologizowanego toponimu, zmienił zatem jego wykładnię semantyczną, czego konsekwencją było przeniesienie go z grupy nazw topograficznych do grupy nazw kulturowych.

\section{Pseudoetymologie wywodzące toponimy od słownictwa książkowego ${ }^{7}$}

Panuje przekonanie, że wtórnej etymologizacji podlegają wyrazy rzadziej używane i słabo znane przeciętnym użytkownikom języka oraz że są one remotywizowane przez wyrazy często używane, dobrze znane wszystkim osobom posługującym się polszczyzną. Prawidłowość ta nie dotyczy jednak nazw własnych, ponieważ nie mają one znaczenia

${ }^{5}$ Tylko różnica odniesienia podstawowego antroponimu występuje też między etymologią naukową i nienaukową nazwy wsi Wagi w Łomżyńskiem: według dokumentów pierwszym mieszkańcem wsi był Wawrzyniec Waga, a według niektórych mieszkańców wieś założył Jakub Waga. Przyczyną błędnego wywodzenia toponimu Wagi od innego nosiciela (proto)nazwiska Waga nie jest jednak błędne przywołanie etymologii naukowej, ponieważ o łączeniu przez mieszkańców Wag nazwy tej wsi z XIX-wiecznym przyrodnikiem Jakubem Wagą zadecydowało nadanie w 1962 roku tutejszej szkole jego imienia; od tego czasu Jakub Waga stał się w rejonie obsługiwanym przez wagowską szkołę osobną postacią przynajmniej z imienia i nazwiska.

6 „Wieś założona w 1402 r. przez Mikołaja Modzela, na ziemi otrzymanej od księcia Janusza” (Modzele).

7 Wyrażenia słownictwo książkowe używam tutaj nie w odniesieniu do rejestru stylistycznego obejmującego wyrazy odbierane jako wyszukane, szczególnie staranne, lecz na określenie leksemów opisujących wiedzę książkową, specjalistyczną. 
leksykalnego, jakie przysługuje wyrazom pospolitym ${ }^{8}$, i w związku z tym są bardziej podatne na wszelkie zabiegi, dzięki którym mogłyby wtórnie zyskać takie znaczenie. Dlatego w procesie reinterpretacji etymologicznej nazw miejscowych po stronie wtórnych wyrazów podstawowych często biorą udział również słowa rzadkie, w tym różnego rodzaju leksemy dawne i specjalistyczne. Niektórym pseudoetymologom pomysłów w typowaniu dla reetymologizowanych toponimów wtórnych wyrazów podstawowych dostarczają naukowe opracowania słownikowe i monograficzne.

Elżbieta Michow w książce o etymologiach ludowych toponimu Kielce podawanie jako wtórnych wyrazów podstawowych słownictwa dawnego tłumaczy inspiracjami słownikowymi i terminologicznymi, przypuszczając, że autorzy niektórych pseudoetymologii ,żywo zainteresowani rozwikłaniem tajemnicy toponimu, prawdopodobnie wertowali słowniki dawnej polszczyzny w poszukiwaniu wiarygodnej podpowiedzi” (Michow 2008: 157).

W wielu źródłach leksykograficznych, a także w gramatykach historycznych i historiach języka polskiego - ale nie w zasobie leksykalnym współczesnych Polaków - można znaleźć na przykład rzeczownik reż 'żyto', od którego rzekomo pochodzi toponim Resko ${ }^{9}$ (pow. łobeski, woj. zachodniopomorskie), por. „Wielu ludzi sądzi, że nazwa „Resko” wywodzi się z powszechnie używanego do XV wieku wyrazu REŻ oznaczającego żyto" (Resko).

Ilustrację dla zjawiska wyprowadzania przez etymologie nienaukowe reetymologizowanych toponimów od słów, których trzeba szukać w słownikach historycznych języka polskiego, stanowi też pseudoetymologia nazwy miejscowej Toszek ${ }^{10}$ (pow. gliwicki, woj. śląskie), w świetle której nazwę tego miasta utworzono od wyrazu tasik 'buda kramarska' (Rogowska-Cybulska 2014), por.: „Być może pochodzi ona od słowiańskiego określenia „tasik” - buda kramarska. Należy tu wspomnieć, że Toszek leżał na jednej z odnóg ,szlaku bursztynowego" i na szlaku handlowym wschód-zachód” (Toszek).

Rzeczownika tasik nie notuje wprawdzie Słownik staropolski ${ }^{11}$, ma on jednak poświadczenie w Słowniku wileńskim (Swil 1961: II, 1906) („tasz, tas, tasik - buda kramarska płachtami okryta, kram pod namiotem") i w Słowniku warszawskim (SW 1953: VIII, 31) (,Kupcy po miasteczkach z kramami, kramikami, taszami, tasikami przejeżdżający, nie wprzód tasze swoje rozbijać będą, aż rejestra towarów urzędowi podadzą").

Staropolski rodowód i zarazem specjalistyczny status terminów z zakresu historii wojskowości decydują o nieznajomości przez przeciętnych użytkowników współczesnej polsz-

\footnotetext{
${ }^{8}$ Po długiej dyskusji na temat problemu znaczenia nazw własnych najczęściej przypisuje się im znaczenie kategorialne, gramatyczne, emotywne, metaforyczne, pragmatyczne, asocjacyjne, historyczne, strukturalne i etymologiczne. Por. Kaleta 1998: 25-27.

${ }^{9}$ Stanisław Rospond (Rospond 1984: 327) i Kazimierz Rymut (Rymut 1987: 205) wywodzą nazwę miasta od nazwy rzecznej Rega. Natomiast ,niezupełnie jasna jest etymologia tej n. rz. (niektórzy nawet łączą ją z Rugia, wyspą lechicką). Rzecz znamienna, że u Ptolemeusza jest wymienione u ujścia Odry polis Rougion. Czy podstawą jest ps. rdzeń *rъg- (reż, żyto)?" (Rospond 1984: 327).

${ }^{10}$ Dawne nazwy elementów architektonicznych często występują w podstawach etymologicznych reetymologizowanych toponimów. Zdaniem S. Rosponda „był to pierwotnie prawdopodobnie Toszecz, tj. n. dzierż. na -jb od nazwy osobowej (właściciel grodu) Toszek (skrócenie imienia Tolisław lub Tolimir [...])" (Rospond 1984: 398). K. Rymut, podobnie interpretując nazwę miasta, sądzi jednak, że jeśli chodzi o nazwy osobowe Toszek, Toszkowic itp., to „pochodzą one od bazy Tosz-, a ta od imion złożonych typu Tomisław lub też od imienia chrześcijańskiego Tomasz" (Rymut 1987: 247).
}

${ }^{11}$ A wzmianka o szlaku bursztynowym sugerowałaby prastarą genezę toponimu Toszek. 
czyzny rzekomych wyrazów podstawowych toponimu Sambory ${ }^{12}$ (pow. łomżyński, woj. podlaskie), przypisanych mu przez dwie pseudoetymologie rozpowszechniane na stronach internetowych promujących walory turystyczne ziemi łomżyńskiej. W świetle jednej z nich nazwa miejscowa Sambory pochodzi od słowa samborza 'wieża strażnicza', por.:

Przyjmując Narew jako arterię komunikacyjną i linię obrony wzmocnioną grodami, osadnictwo mazowieckie posuwało się ku północy między rzekami Biebrzą i Skrodą. W pobliżu przeprawy pod Wizną skupiały się osady bronione dodatkowym grodem w Samborach, w miejscu łączenia się Biebrzy z Narwią. Charakterystyczna nazwa (staropolska samborza - wieża strażnicza) tego grodu datuje go na wczesne średniowiecze przed końcem XIII w. (Sambory).

Rzeczownik rodzaju żeńskiego samborza został zarejestrowany w Słowniku staropolskim, w którym jest on opisany jako wariant form szamburza i szymborza o znaczeniu 'wieża obronna nad bramą wjazdową' (Sstp 1977-1981: VIII, 118)'13.

Druga etymologia nienaukowa toponimu Sambory w funkcji jego wtórnego wyrazu podstawowego obsadza rzeczownik rodzaju nijakiego samborze 'obronny szaniec mostowy', por.:

Sambory, wzniesienie po strategicznie położonym u zbiegu rzek grodzisku z XI-XIII w., pilnującym szlaku handlowego z Mazowsza na Litwę (Biebrzą) i Ruś (Narwią). Świetnie wynalezione przez przodków miejsce obserwacyjne prezentuje i dzisiaj niezrównany widok na ujściowe odcinki Biebrzy i Narwi oraz obydwa bagna: Ławki i Wizna. Wiosną tworzy się w tym miejscu wielokilometrowa tafla wodna, na której zatrzymują się na popas tysięczne stada przelotnych ptaków. Nazwa wsi pochodzi od obronnego szańca mostowego, zwanego samborzem, broniącego w XVI w. mostu przez Narew (Samborze 2).

Leksem samborze notuje Stownik języka polskiego pod redakcją Witolda Doroszewskiego (dostępny też w wersji internetowej), opatrując to słowo kwalifikatorem hist. i definiując je jako 'pięterka po bokach bramy i nad bramą (ogrodzenia lub obwarowania), przeznaczone na mieszkanie wartownika'14.

Jako termin etnograficzny i archeologiczny traktuje Elżbieta Michow jedną z wtórnych podstaw motywacyjnych nazwy miejscowej Kielce ${ }^{15}$, apelatyw kleć 'licha, marna budowla,

12 Sambory to według etymologii naukowej nazwa rodowa od imienia Sambor (Zierhoffer 1957: 329; Halicka 1976: 152; NMP 2016: XIII, 35).

${ }_{13}$ Objaśnienie to powtarza internetowa Wikipedia, powołująca się na Stownik staropolski (Samborze).

${ }^{14}$ W Wikipedii zaś pod hasłem samborze zamieszczono objaśnienie o treści: „w dawnej Polsce pięterka po obu stronach bramy wjazdowej, przeznaczone na mieszkanie wrotnych stróżów, do którego schody prowadziły po wewnętrznej stronie podwórza. Niekiedy samborza takie były uzbrojone"; dodatkowe wiadomości na temat budowy i przeznaczenia tego obiektu architektonicznego pochodzą zapewne z Życia polskiego w dawnych wiekach Władysława Łozińskiego (Samborze 1).

Autorzy pseudoetymologicznych wykładni nazwy miejscowej Sambory dość swobodnie operują wiedzą językoznawczą, dostosowując ją do lepiej rozpropagowanych hipotez archeologicznych, według których ,istniejący pośrodku grodziska wał długości $25 \mathrm{~m}$ i szerokości $10 \mathrm{~m}$ może być pozostałością wybudowanej w tym miejscu wieży" Brodzicki 1994: 24

15 Jeśli chodzi o etymologię naukową nazwy Kielce, to zdaniem Marii Malec „najbardziej prawdopodobna jest teza o jej topograficznym charakterze. Nazwa pochodzi przypuszczalnie od wyrazu $* k l e c$ z ps. $* k b l b c b$ 'kiełek', zdrobniałej formy od kiel, ps. *kъlъ, w liczbie mnogiej kielce 'kiełki'. Nazwa Kielce mogła określać pierwotnie 'teren podmokły, porośnięty krzakami, zaroślami, kiełkami'. Mniej prawdopodobne jest przypuszczenie o odosobowym pochodzeniu tej nazwy, tj. nazwy typu rodowego od nazwy osobowej Kielec, w liczbie 
lepianka; spichlerz', przejęty jej zdaniem przez pseudoetymologów z prac naukowych dotyczących tych dziedzin, por.:

Do powstania pseudoetymologii opartych na rdzeniu kleć- 'budować' i wyraz[ach] kleć, klec, klecie, klety mogli się nieświadomie przyczynić etnografowie, archeolodzy i historycy, używający w swoich opracowaniach terminu specjalnego kleć lub klecie, następnie skojarzonego przez niektórych z toponimem Kielce (Klece). Termin klecie używany jest przez K. Moszyńskiego w Kulturze ludowej Stowian oraz J. Kuczyńskiego w pracach archeologicznych (opisujących wygląd dość prymitywnych palenisk i domostw w starokieleckiej osadzie) (Michow 2008: 157).

Terminem włókienniczym, dziś już stanowiącym archaizm rzeczowy, używanym jednak w słownikach i w opracowaniach historycznych na temat przemysłu tekstylnego, jest natomiast rzeczownik cyc 'tkanina bawełniana importowana z Indii, od XVII w. produkowana w angielskich i francuskich manufakturach, najczęściej drukowana w barwne wzory i mocno glansowana w kalandrach; w Polsce wyrabiana w drugiej połowie XVIII w., używana jako lekki materiał odzieżowy i obiciowy" (PSWP 1996: 7, 317), od którego jakoby utworzono nazwę miejscową Cyców ${ }^{16}$ (pow. łęczyński, woj. lubelskie), por.:

Jeszcze inaczej powstała nazwa Cyców (woj. lubelskie). W tej niewielkiej miejscowości wciąż trwa pamięć o produkowanym w tamtejszej manufakturze suknie zwanym „,cycem”, nazwa miejscowości u nikogo nie wzbudza śmiechu, a raczej sentyment za dawno minionymi czasami świetności (Cyców 1).

Ten sam toponim bywa też reinterpretowany jako derywat ${ }^{17}$ od terminu geologicznego jeziora cycowe 'jeziora typu bezodpływowego', nieznanego słownikom ogólnej polszczyzny, por::

Miejscowość [Cyców] intryguje i zaciekawia swą oryginalnie brzmiącą nazwą. Po raz pierwszy w dokumentach historycznych pojawia się na przełomie XIV i XV wieku; została najprawdopodobniej utworzona od hydronimu jezior cycowych (jezior typu bezodpływowego) (Cyców 2).

Do wtórnych wyrazów podstawowych przejmowanych przez pseudoetymologów z tekstów naukowych, ewentualnie z wtórnych wobec nich źródeł internetowych, należą również niektóre nazwy własne. Szczególnie często w funkcji wtórnych podstaw motywacyjnych występują nazwy pogańskich bóstw, znane zazwyczaj reinterpretatorom z lektury naukowych opracowań na temat dziejów religii (por. Rogowska-Cybulska 2015a). Jako

mnogiej Kielce" (Malec 2003: 122-123). S. Rospond dopuszcza też interpretację 'gród na wzgórzu otoczony ktami, czyli palisadą' (S. Rospond 1984: 984, 140), zestawia też tę nazwę z wyrazem „kiet = 'odziomek drzewa, pnia drzewnego po ścięciu', por. jeszcze gwar. kło = 'poręba, na której sterczy pełno odziomków"” (Rospond 1984: 141).

${ }^{16}$ Toponim Cyców to - zdaniem Barbary Czopek-Kopciuch - derywat utworzony sufiksem -ów od nazwy osobowej Cyc (NMP 1997: II, 162).

17 Pseudoetymologowie nie zajmują się na ogół opisem struktury, jaką miałyby reetymologizowane toponimy w świetle ich objaśnień, jednak - gdyby przyjąć tę koncepcję - musiałaby to być formacja paradygmatyczno-dezintegralna. Por. Rogowska-Cybulska 2015b). 
przykład niech posłuży teonim Jastrzebóg, od którego jakoby powstała nazwa miejscowa Jastarnia $^{18}$ (pow. pucki, woj. pomorskie), por.:

Nazwa dzisiejszego miasta, według legendy, pochodzi od pogańskiego bożka Jastrzeboga, któremu oddawano cześć, paląc ognie i tańcząc wokół posągu. Rytuały te działy się na wzniesieniach i były odprawiane zawsze na początku wiosny. Jak głosi legenda, na jednym z takich właśnie wzniesień, powstała osada, która później przerodziła się w dzisiejsze miasto (Jastarnia).

Stosunkowo rzadko natomiast uwiarygodnieniu pseudoetymologii służy wierne przywołanie we wtórnej wykładni semantycznej formy ortograficznej, w jakiej wyraz wybrany na rzekomą podstawę motywacyjną pojawia się w dawnych dokumentach i którą wydobyto z opracowań naukowych przytaczających te dokumenty. Ilustracją takiej sytuacji może być zapis pecare, kryjący polski rzeczownik pieczara 'pozostałość po pracach górniczych', od którego ponoć utworzono toponim Piekary ${ }^{19}$ (woj. śląskie), por.:

Trzecia legenda podaje, że nazwa Piekary wywodzi się od pieczar, których dość duża liczba znajdowała się na okolicznych terenach. Pieczary, to pozostałości po pracach górniczych na tym terenie, eksploatacji w XII wieku rud żelaza lub srebra. W dokumentach używano słowa Pecare, co oznacza pieczarę (Piekary).

Częściej naukowa wiedza twórców pseudoetymologii ujawnia się w wybieraniu na wtórne podstawy motywacyjne nieznanych powszechnie wyrazów obcojęzycznych. Prawdopodobnie do skojarzenia przez miejscową inteligencję nazwy miasta Kościerzyna ${ }^{20}$ (woj. pomorskie) z łacińskim wyrazem castrum 'gród' wystarczyła zresztą szkolna znajomość łaciny, por.:

Inna interpretacja pochodzenia nazwy Kościerzyna odwołuje się do historycznych zapisów tej nazwy i głosi, że jej podstawą jest rzeczownik łac. castrum 'gród', od którego przez dodanie przyrostka -ina//-yna miałaby powstać interesująca nas nazwa miejscowa. Objaśnienie to nie jest notowane w literaturze, powtarzane jest ustnie i staje się dość popularne wśród miejscowej inteligencji (Breza 1999: 130).

Zapewne dobre opanowanie języka łacińskiego w seminarium duchownym pozwoliło jednemu z proboszczów w Przytułach wywodzić nazwę leżącej w tej parafii wsi Wagi ${ }^{21}$ (pow. łomżyński, woj. podlaskie) od liczby mnogiej rzeczownika vagus 'włóczęga', por.:

18 Jastarnia nie ma pewnej etymologii. Wywodzona bywa albo od rodzimego przymiotnika jaster 'jasny, błyszczący', albo od germańskiego Ostern łączącego się ze wschodem, jasnością i skandynawskiego nes 'przylądek'; ewentualnie od stgniem. östern 'wschód' i nest 'gniazdo' (Rospond 1984: 122).

19 Jak pisze M. Malec, „była to pierwotnie osada polska zamieszkała przez piekarzy wykonujących swój zawód w ramach książęcej gospodarki służebnej” (Malec 2003: 189). S. Rospond podaje, że „służebność piekarska była jedną z podstawowych powinności dla grodu, w tym wypadku dla prastarego Bytomia. Dość częste są n.m. identyczne, które pierwotnie miały postać Piekarze" (Rospond 1984: 287).

${ }^{20}$ W rzeczywistości toponim Kościerzyna został utworzony przyrostkiem -ina od gwarowego rzeczownika kościerz 'zarośla, krzewy', kasz. ‘drzewa gałęziste, rosochate’ (Malec 2003: 129-130).

${ }^{21}$ Według etymologii naukowej toponim Wagi jest nazwą rodową, utworzoną od imienia prusko-jaćwieskiego Waga, spokrewnionego z litewskim waga 'bruzda, koryto rzeki, zagon', litewskim vanga 'pole, rola' i pruskim vangus 'dąbrowa, las w części uprawiany rolniczo' (Wiśniewski 1974: 9-10). 
„od słowa z języka łacińskiego vagus - 1.mn. vagi - włóczędzy, przybysze - bo przybyli $\mathrm{z}$ Prusę 22 .

Ale już powiązanie toponimu $P y z d r y^{23}$ (pow. wrzesiński, woj. wielkopolskie) z łacińskim rzeczownikiem pistrinum 'młyn' wymagało chyba sięgnięcia do słownika łacińsko-polskiego, por.: „Historycy natomiast twierdzą, że nazwa pochodzi od łacińskiego słowa „pistrinum”, oznaczającego młyn, których było tutaj sporo” (Pyzdry).

Prawdopodobnie w słowniku znaleziono również wtórną podstawę motywacyjną nazwy Kielce w postaci łacińskiego rzeczownika calx 'wapno, wapień' (a ściślej: jego dopełniacza calcis), o czym wiemy tylko z krytycznego zreferowania tej koncepcji przez W. (pełne imię) Gierowskiego, por.: „Bezkrytyczne i naiwne jest wyprowadzanie nazwy Kielce [...] od łacińskiej nazwy wapna: calx (kalks), „calcis” - (kalcis)” (Gierowski 1961)24.

O książkowej erudycji twórców etymologii nienaukowych świadczy również wyprowadzanie polskich toponimów ze starożytnej greki. Taką właśnie obcą motywację proponują pseudoetymolodzy dla nazwy miasta $P \nmid o c k^{25}$ (woj. mazowieckie), która ma pochodzić „od ploto czyli po grecku ,spływ, żegluga”.

Autorzy niektórych hipotez pseudoetymologicznych przy szukaniu wyrazów podstawowych dla reetymologizowanych toponimów niewątpliwie korzystają też ze słowników etymologicznych, przeglądając hasła dotyczące innych obiektów topograficznych. W ten zapewne sposób powstała jedna z etymologii nienaukowych nazwy miasta Chorzele ${ }^{26}$ (pow. przasnyski, woj. mazowieckie), wyprowadzająca ją od bałtyckiego słowa (h)orz 'koń', por.: „Inne wytłumaczenie zakłada pochodzenie nazwy [Chorzele] od bałtyjskiego słowa orz, co oznacza koń, od którego bierze się też nazwa pobliskiej rzeki Orzyc. Używano różnych wersji: orz lub horz, a stąd już bardzo blisko do chorz-" (Chorzele).

Ślady lektury słowników etymologicznych znajdziemy również w quasi-naukowej obudowie pseudoetymologii, według której toponim Warszawa ${ }^{27}$ pochodzi od słowiańskiego antroponimu Sawa i niesłowiańskiego apelatywu war, powiązanego z węgierskim wyrazem warosz 'warownia' oraz toponimami Bar i Bardo, por.:

${ }^{22}$ Informacja przekazana na piśmie od Tadeusza Górskiego z Łomży.

${ }^{23}$ Zdaniem S. Rosponda „Ponieważ było przezwisko Pizdura (por. Pizdury, n. rod. w dawnym pow. nowotarskim), dlatego jedynie możliwa interpretacja Pyzdr byłaby Pizdury n. rod. 'pogardliwe przezwisko kobiety' i wiele innych znaczeń, por. piznąć. [...] Można też przyjąć przezwisko Pizder; por. gw. pizder, też pizer = 'biedak, chuchrak', pizdrowaty = 'mizerny'. Niewątpliwie była to n. rod. Tłumaczono też Pyzdry od podstawy pis- (Pisa) oraz pod podstawy py-//pu-, pie. *pu-, *peu- 'nadymać, pucnąć', ale niejasna jest przy tym wywodzie budowa nazwy, tj. przyrostek -zdr- lub -zr-" (Rospond 1984: 317).

${ }^{24}$ Cyt. za: Michow 2008: 110.

${ }^{25}$ Różne koncepcje etymologiczne dotyczące tej nazwy streszcza M. Malec: „Nazwa jest utworzona za pomocą przyrostka *bsk- od podstawy płot-, wieloznacznej. Dawniej zestawiano ją z wyrazem płot 'ogrodzenie, zagrodzenie'. Niektórzy badacze znajdowali odpowiedniość w ruskiej nazwie miejscowej Połock, leżącej nad rzeką o nazwie Polota. W nazwach tych upatruje się dziś związek z ie. pierwiastkiem *pl-t-, *pel-t-, *pol-to znaczeniu 'otwarta płaszczyzna' albo raczej 'rzeka'. Mniej prawdopodobna jest etymologia germańska" (Malec 2003: 193).

${ }^{26}$ Nazwa miejscowa Chorzele pochodzi od nazwy „gaju Chorzele, na terenie którego założono osadę” (NMP 1997: II, 73). Nazwa gaju jest objaśniana jako utworzona od nazwy osobowej Chorzela, motywowanej przymiotnikiem chory lub czasownikiem chorzeć.

27 Warszawa, pierwotnie Warszewa, to nazwa dzierżawcza od antroponimu Warsz, skróconej postaci imienia Warcisław (Rospond 1984: 414). 


\begin{abstract}
Warszawa - prawdopodobnie nazwa dwuczłonowa War Sawa. Sawa to oczywiście imię i to nawet chyba męskie. Ciekawie czy jeszcze dotąd używane. Prawdopodobnie słowiańskie, może ktoś będzie wiedział co znaczy. Natomiast słowo „war” jest dosyć stare, pochodzenia niekoniecznie słowiańskiego. Podobne odnajdziemy w języku węgierskim, warosz oznacza miasto. Dla koczowniczych ludów ugrofińs[k]ich jakimi byli węgrzy [tak!] gdy pojawili się w puszcie i nad Balatonem pojęcie miasta raczej nie istniało. Musiało więc oznaczać tyle co miejsce umocnione, zamek czy fort. Potwierdzałoby to istnienie wielu innych miejscowości typu Bar, Bardo gdzie litera „b” wymieniła literę „w” (taka wymiana w językach często się zdarza), bądź zawierających podobny rdzeń. Również używane dotąd w języku polskim słowa „warownia”, „warowny" mają taką właśnie jednoznaczną konotację. Jeżeli tak to nazwa stolycy [tak!] znaczy tyle co Fort Sawy. Nawiasem mówiąc pierwotne położenie (obecnie stolyca się rozbudowała) doskonale uzasadniałoby przeznaczenie zgodne z takim rozumieniem nazwy. Pozostaje tylko pytanie kto to był ten Sawa? Samodzielny włodarz czy też oddany żołnierz na posterunku, założyciel czy dowódca fortu? No i oczywiście kiedy i w jakich okolicznościach się realizował (Warszawa).
\end{abstract}

\title{
Wiedza naukowa we wtórnych wykładniach etymologicznych
}

Kolejny przejaw obecności wiedzy naukowej w nienaukowych etymologiach nazw miejscowych to włączenie jej fragmentów do wtórnych wykładni semantycznych reetymologizowanych toponimów, co zachodzi w dwu sytuacjach: podczas udowadniania hipotez naukowych z innych dziedzin niż onomastyka i podczas uwiarygodniania etymologii nienaukowych informacjami z różnych dziedzin nauki.

Zdarza się, że właśnie autorskie pseudoetymologie wybranych toponimów stanowią ilustrację propagowanych przez niejęzykoznawców poglądów naukowych, co zaobserwowała m.in. E. Michow, badając etymologie ludowe toponimu Kielce:

Nienaukowa etymologia pojawiała się niekiedy pomocniczo dla zilustrowania hipotez autora $\mathrm{z}$ różnych dziedzin naukowych, niejako na marginesie właściwego wykładu geograficznego, archeologicznego, historycznego, etnograficznego, kulturowego. Ważną funkcję w regionalnej literaturze naukowej posiadały pseudetymologie od kielce i klece, służące historykowi J. Pazdurowi do udowodnienia i propagowania autorskiej tezy o pierwotnym służebnym charakterze osady (na potwierdzenie którego brak dowodów historycznych czy archeologicznych) (Michow 2008: 153-154).

J. (pełne imię) Pazdur swoje objaśnienie pseudoetymologiczne wywodzące toponim Kielce od apelatywu kielc 'osoba wyrabiająca ostro zakończone narzędzia' sformułował w ramach hipotezy historycznej o niekasztelańskich charakterze pierwotnych Kielc, por.:

Nazwa Kielce byłaby obocznością do Grotników i trzeba by ją zaliczyć do kategorii osad służebnych. Byłby to rozstrzygający dowód, że Kielce nie były siedzibą kasztelańską, gdyż osady służebne zakładano z inicjatywy pierwszych Piastów właśnie dla systematycznego zaopatrywania grodów kasztelańskich $\mathrm{W}$ aprowizację, narzędzia, naczynia lub fachowe usługi (Pazdur 1967: 22$)^{28}$.

${ }^{28}$ Cytat za: E. Michow 2008: 121. 
Zygmunt Gloger, autor Encyklopedii staropolskiej, pseudoetymologią wyprowadzającą toponim Wizna ${ }^{29}$ (pow. łomżyński, woj. podlaskie) od niepoświadczonego w źródłach rzeczownika wyźnia 'wyżyna' (Rogowska-Cybulska 2012) ilustruje natomiast tezę o potrzebie szukania pozostałości średniowiecznych grodów na wysokich miejscach, por::

Za doby Piastów, Mazowszanie tutejsi, granicząc z dziewiczemi puszczami Podlasia, w których tylko dziki zwierz miał swoje legowiska lub Jadźwing łupieżca podkradał się z północy, zabezpieczali swoją ziemię budowaniem warownych zamków, czyli „grodów”, po których dotąd pozostały potężne usypiska. Główne z nich, jakby stolica tych ziem, znajduje się przy miasteczku Wiźnie, na panującej nad Narwią ,wyżynie” czyli „wyźni”, od której i nazwa tego grodu (Wizna) wzięła początek Gloger 1903: 216).

Najczęściej jednak wiedza naukowa wykorzystywana przy konstruowaniu etymologii nienaukowych toponimów stanowi pozajęzykowy argument uwiarygadniający ich prawdziwość. Ponieważ celem wtórnych wykładni semantycznych jest zasadniczo „rekonstrukcja” znaczenia nazwy miejscowej w momencie jej powstania, twórcy pseudoetymologii zwykle wspomagają się wiedzą historyczną.

Jako przykład etymologii nienaukowej odwołującej się do historii politycznej można przywołać jedną z pseudoetymologii nazwy wsi Chrzelice ${ }^{30}$ (pow. prudnicki, woj. opolskie). Tekst zamieszczony na stronie internetowej tej miejscowości - fragment opowiadania pt. O popowym lasku i chrzcelickim zamku autorstwa śląskiego pisarza i gawędziarza Rafała Urbana (1893-1972) - objaśnia nazwę wsi poprzez jej zestawienie ze słowami (o) chrzcić, chrzcielnica, *chrzcielic 'chrzciciel' i chrzciciel, por.:

[Święci Cyryl i Metody] Ochrzcili Ślązaków i Krakowiaków jako pierwszych ze wszystkich Polaków. A żeby ochrzcić dokładnie tych nie okrzesanych i nie umytych dzikusów, kazali budować na chrzcielickim zamku, który wtedy jeszcze drewnianym grodziskiem był i zgoła inaczej się nazywał, studnię szeroką i murowaną. Nazywa się taka studnia baptysterion, czyli chrzcielnica. A stąd właśnie te Chrzcielnice pochodzą. Bo Chrzcielice to znaczy chrzciciele (Chrzelice).

Od strony (pseudo)faktograficznej zwolennicy tej pseudoetymologii wiążą natomiast powstanie nazwy wsi z działalnością świętych Cyryla i Metodego, którą opisują na podstawie historycznej wiedzy o misji braci sołuńskich, por.:

\footnotetext{
${ }^{29}$ Nazwa Wizna nie ma dotąd pewnej etymologii naukowej, zwłaszcza że nie przesądzono również, co było pierwotnie jej desygnatem. Zdaniem Zbigniewa Babika „może była to późniejsza rzeka Wiźnica, może rozległe błota u zbiegu dwu rzek" (Babik 2001: 318). K. Zierhoffer w Nazwach miejscowych pótnocnego Mazowsza uznaje tę nazwę za niejasną (Zierhoffer 1957: 380). Na ogół uważana jest ona za nazwę niesłowiańską, bałtycką. Najczęściej bywa zestawiana z pruskim rzeczownikiem wizene 'trawa', zamieszczonym przez Aleksandra Brücknera w jego Stowniku etymologicznym języka polskiego s.v. wisz 'sitowie' (Brückner 1974: 625). Taką hipotezę podają m.in.: Irena Halicka, por.: „n. niejasna, być może top., por. prus. wizene “trawa”” (Halicka 1978: 77); Kazimierz Rymut, por.: „pochodzenie nazwy nie jest jasne. Być może, iż utworzona została od staropruskiego wizene «trawa»” (Rymut 1987: 265); a także Stanisław Rospond, por.: „Identyczna n. m. Wizna leży w dawnym pow. słuckim (Wizna 1145 r.) i obie są prawdopodobnie pochodzenia bałt.; por. stprus. wizene $=$ 'trawa'. Spolszczenie jednak nastąpiło bardzo dawno" (Rospond 1984: 429).

${ }^{30}$ Ten sam tekst podaje, że S. Rospond rekonstruuje pierwotną postać Chorzelice i interpretuje ją jako nazwę patronimiczną od antroponimu Chorzela. Dwie inne etymologie ludowe wyprowadzają nazwę Chrzelice od rzeczowników krzela 'skrzela' oraz krze 'krzewy'.
} 
Pierwsza z nich [interpretacji toponimu Chrzelice] wywodzi nazwę od starosłowiańskiego słowa chrzcielnica (chrzcielnia), chrzcić (krzcić, chrscic, chrzczę, krzczę) lub chrzest (krzest, krztu, krzsta). Oparta jest na motywach legendy o dwóch misjonarzach braciach, świętym Cyrylu (826-869 pierwotnie Konstantyn, dopiero po wstąpieniu do klasztoru przybrał imię Cyryl) i świętym Metodym (815-885), którzy znacząco przyczynili się do wprowadzenia ziem słowiańskich w krąg kultury chrześcijańskiej. Na prośbę księcia morawskiego Rościsława w 863 roku udali się na Morawy, aby szerzyć tam chrześcijaństwo. W tym właśnie okresie wg legendy obaj bracia z Moraw zawędrowali aż na nasze ziemie gdzie mieli udzielać nauk oraz chrztu chrzelickiej i okolicznej ludności (Chrzelice).

W nienaukowej etymologii toponimu Wiślica ${ }^{31}$ (pow. buski, woj. świętokrzyskie), wyprowadzającej go od niepotwierdzonego imienia Wiślimir, deklarowane jest nawet źródło informacji o szczegółach chrztu ${ }^{32}$ rzekomo noszącego to imię księcia Wiślan - Żywot Świętego Metodego, zwany też Legenda panońska, por.:

Wiślica istnieje co najmniej od IX wieku. Według legendy nazwa osady pochodzi od imienia jej założyciela, księcia Wiślan Wiślimira, który wraz ze swoim otoczeniem miał przyjąć chrzest w 880 roku. Wspomina o tym tzw. legenda panońska, czyli Żywot św. Metodego. Dokument mówi o przymusowym chrzcie pogańskiego księcia Wiślan (Wiślica).

Pseudoetymologicznemu stwierdzeniu, że toponim Losice $^{33}$ (woj. mazowieckie) pochodzi od rosyjskiego wyrazu лошадь 'koń', towarzyszy wzmianka o hodowaniu tu koni już w okresie przynależności miasta do Wielkiego Księstwa Litewskiego oraz o jarmarkach końskich odbywanych w Łosicach od XVI wieku, zaczerpnięta z historii gospodarczej Podlasia, por.:

Zastanawiałam się skąd nazwa Łosice. Pierwsze, co przyszło mi do głowy to łoś, albo pani łosiowa. Moja teoria łosia i łosicy okazała się jednak błędna. Okazuje się, że nazwa Łosice pochodzi od koni, które jak wiadomo w języku rosyjskim noszą nazwę „loszadi”. Poza tym Łosice w wieku XVI posiadały w herbie konia, a jeszcze przed założeniem miasta, bardzo popularne były w tej okolicy koniki leśne-tarpany. „W okresie przynależności Podlasia do Wielkiego Księstwa Litewskiego na okolicznych łąkach wypasały się stada litewskich koni, stanowiących rezerwę kawalerii litewskiej w wypadku wyprawy wojennej." Herbem Łosic jest biegnący koń, co również potwierdza pochodzenie nazwy miasta. ,[...] Nie bez znaczenia były także jarmarki i targi urządzane regularnie w Łosicach od XVI wieku, gdzie handel końmi stanowił dość znaczny udział" (Jędruszuk).

Historię gospodarczą reprezentują również często podawane w etymologiach nienaukowych szczegóły dotyczące przebiegu szlaków komunikacyjnych w okresie, w którym została założona miejscowość nosząca reetymologizowaną nazwę ${ }^{34}$. Przykładem może być

31 Według badań onomastycznych nazwa tej miejscowości miała pierwotnie formę Wisła i była identyczna z nazwą rzeczną lub urobiono ją od nazwy etnicznej Wiślanie (Rospond 1984: 428).

32 Motyw chrztu często występuje w etymologiach ludowych polskich toponimów. Por. Rogowska-Cybulska 2016b)

33 Nazwa Łosice jest nazwą dwuznaczną, patronimiczną (od przezwiska Łoś) lub topograficzną (od apelatywu toś) (Rospond 1984: 206-207).

34 Motyw transportu często występuje w etymologiach ludowych polskich toponimów. Por. E. RogowskaCybulska 2016a. 
jedna z pseudoetymologii nazwy miejscowej Gostków $w^{35}$ (pow. poddębicki, woj. łódzkie), por:

Etymolodzy nazwę miejscowości Gostków wiążą z położeniem jej przy gościńcu. Wywód ten jest słuszny, bowiem miejscowość ta położona jest na skrzyżowaniu średniowiecznych traktów z Uniejowa do Parzęczewa, z Łęczycy do Poddębic i dalej do Szadku i Sieradza. Pierwsze pisane wzmianki o Gostkowie pochodzą z lat 1391-1392 (Gostków).

W pseudoetymologiczne objaśnienia genezy reetymologizowanego toponimu wplatane bywają nawet fakty biograficzne, jak w wypadku potocznej etymologii nazwy miejscowej $K_{\text {Kowal }}{ }^{36}$ (pow. włocławski, woj. kujawsko-pomorskie), wiązanej z historycznie potwierdzonymi narodzinami w tym mieście króla Kazimierza Wielkiego, por.:

Stare ludowe podania mówią, że Kazimierz Wielki urodził się w domu kowala i stąd na pamiątkę tego faktu miała powstać nazwa miasta. [...] Przejeżdżając przez tę miejscowość w drodze z Kruszwicy do Krakowa, Królowa Jadwiga, córka księcia kaliskiego Bolesława Pobożnego $\left({ }^{*} 1221,+13.04 .1279\right)$ zatrzymała się w grodzie aby odpocząć. W tej miejscowości 30 kwietnia 1310 roku urodziła syna Kazimierza III zwanego później Wielkim, ostatniego króla polski (tak!) z dynastii Piastów, syna Władysława I Łokietka $(* 1260,+02.03 .1333)$ (Kowal).

Etymologie nienaukowe kryją też w sobie bogactwo detali z zakresu historii lokalnej. Na przykład nazwę Radziejów $w^{37}$ (woj. kujawsko-pomorskie) potocznie reinterpretatorzy thumaczą odbywaniem tu do rozbiorów Polski rad, czyli sejmików ziemi kujawskiej, por: „M. Borucki w „Ziemi Kujawskiej” nazwę Radziejowa także od rad i wieców wywodzi. Radziejów od najdawniejszych czasów, aż do upadku Polski był miejscem, w którym odbywały się zjazdy sejmików kujawskich" (Radziejów).

W pseudoetymologii nazwy miejscowej Cieszowa ${ }^{38}$ (pow. lubliniecki, woj. śląskie), remotywowanej nazwiskiem Cieszkowski, mowa o roku nabycia wsi przez przedstawicieli tej rodziny, por.: „Cieszowa należy do najstarszych miejscowości gminy Koszęcin i zapewne do jednych z najstarszych na ziemi śląskiej. [...] Nazwa była także przypisywana rodzinie Cieszowskich, która nabyła wioskę na własność w 1586 roku, aby pozostawać tam do 1628 roku" (Cieszowa).

Pseudoetymologicznym wyjaśnieniom, że nazwa kurpiowskiej wsi Turośl (pow. kolneński, woj. podlaskie) powstała od frazy Tu rośl, upamiętniającej jakoby fakt, że drzewo sosnowe na budowę tutejszego kościoła pochodzi z tego samego miejsca co ów kościół, towarzyszą w tekście Oskara Kolberga szczegółowe dane na temat dziejów budowy tutejszej świątyni, por.:

Turośl osada z kościółkiem na znacznej górze piaszczystej. Miano to właściwie ma służyć (jak powiadają) kościołowi parafijalnomu około roku 1805 przez Michała Szaniawskiego leśniczego rządowego i wójta gminy wystawionemu; Szaniawski używszy drzewa sosnowego do owej świą-

${ }^{35}$ E. Borysiak wyprowadza ten toponim od nazwy osobowej Gostek (NMP 1999: III, 266).

${ }^{36}$ Zdaniem S. Rosponda „była to osada rzemieślnicza, czyli służ[ebna], w której kowale wykonywali różne usługi dla grodu, położonego obronnie wśród jezior i bagien. A zatem najpierw były to Kowale" (Rospond 1984: $162)$.

${ }^{37}$ Radziejów to nazwa dzierżawcza od podstawy antroponimicznej Radziej (Rospond 1984: 323).

${ }^{38}$ Cieszawa jest nazwą dzierżawczą motywowaną antroponimem Ciesz (NMP 1997: II, 143). 
tyni z tegoż samego miejsca na którem ona dzisiaj stoji, nazwać miał osadę kościelną Tu - rośl (Kolberg 1964: 30).

Oprócz faktów historycznych pseudoetymolodzy w swych wywodach uwiarygadniających wcześniej postawione hipotezy quasi-onomastyczne chętnie wykorzystują rezultaty odkryć archeologicznych. Na przykład etymologia nienaukowa toponimu Konojad ${ }^{39}$ (pow. grodziski, woj. wielkopolskie), objaśniająca jego powstanie jedzeniem przez dawnych mieszkańców tej wsi koniny ${ }^{40}$, powołuje się na wyniki pobliskich wykopalisk, które potwierdzają spożywanie tu końskiego mięsa już w pierwszym tysiącleciu naszej ery, por.:

Nazwa wsi pochodzi najprawdopodobniej od jedzenia koniny. [...] Niedaleko od Konojadu na płd. znaleziono grób wojownika z pierwszego tysiąclecia naszej ery przy którym znajdowały się ślady rytualnej uczty w trakcie której spożywano koninę i stąd można wywodzić aktualną nazwę miejscowości (Konojad 1; Konojad 2).

Rzadziej naukowy charakter mają informacje z zakresu geografii i geologii, przydatne zwłaszcza jako argument za prawdziwością etymologii skojarzeniowych nazw miejscowych reinterpretowanych jako topograficzne ${ }^{41}$. Specjalistyczny opis warunków fizjograficznych okolicy miasta znajdziemy m.in. w etymologii nienaukowej toponimu Strzegom ${ }^{42}$ (pow. świdnicki, woj. dolnośląskie), wyprowadzającej go od wyrażenia trzy góry, por.:

Według innej teorii wywodzi się ją również od warunków fizjograficznych terenu - Wzgórz strzegomskich, na których miasto powstało. Wzgórza te dzielą się na trzy pasma: najwyższe pasmo południowe zbudowane z granitu, średnie środkowe - ciągnące się na północ od linii Rogoźnica-Goczałków Górny-Jaroszów, oraz najniższe pasmo północne. Od ich ukształtowania miała pochodzić pierwotna nazwa Trzy góry, która w wyniku procesów lingwistycznych miała się zmienić później w Strzegom (Strzegom).

Niekiedy we wtórnych wykładniach semantycznych reetymologizowanych toponimów pojawiają się też specjalistyczne wiadomości z dziedziny biologii, jak w wypadku jednej z pseudoetymologii toponimu Lelis ${ }^{43}$ (pow. ostrołęcki, woj. mazowieckie), wiążącej go z gwarowym fitonimem jeglija 'świerk', rzekomo ze względu na przebiegającą w pobliżu tej wsi granicę zasięgu świerka, por.: „Istnieją, również inne przesłanki, świadczące, że

39 Zofia Zierhoffer pisze, że toponim Konojad został utworzony od nazwy osobowej *Konojad 'człowiek, którego cechą wyróżniającą spośród innych ludzi było to, że się żywił koniną’; w połowie XVI w. nazwa wsi przejściowo występowała w liczbie mnogiej (NMP 2003: V, 106). Etymologia nienaukowa wywodzi reetymologizowaną nazwę od wyrażenia będącego w świetle etymologii naukowej pośrednią podstawą motywacyjną: toponim Konojad < antroponim * Konojad < jeść konie.

40 Pseudoetymologiczne objaśnienie nazwy własnej Konojad ma też swoją wersję opartą na potocznej wiedzy historycznej, która wiąże jedzenie koniny z najazdem na Polskę Szwedów, por.: „Według podania zanotowanego przez Oskara Kolberga, swoje konie mieli tu zjeść Szwedzi w czasie „potopu”, gdy zabrakło im innego jedzenia" (Konojad).

41 Zjawisko reinterpretowania nazw miejscowych jako topograficznych jest stosunkowo częste, por. Rogowska-Cybulska 2017.

42 Strzegom to nazwa dzierżawcza od nazwy osobowej Strzegom (Rymut 1987: 231, Rospond 1984: 371).

43 Toponim Lelis pochodzi - zdaniem U. Bijak - od nazwy osobowej Lelis (notowanej w okolicy) lub bezpośrednio od bałtyckiego apelatywu, por. litewskie lělis, lèlys 'ptak wielkości jaskółki latający o zmroku, po polsku lelek’, przy czym podstawa lel- jest słowiańska (NMP 2005: VI, 49-50). 
nazwa pochodzi od świerku „Eglisz”, który na Kurpiach nazwano jegliją, a w okolicach dzisiejszego Lelisa przebiegała granica lasów świerkowych. Gacka” (Lelis).

Przy etymologizowaniu wykorzystywana bywa nawet wiedza z zakresu historii sztuki. $\mathrm{Na}$ przykład wiarygodność etymologii nienaukowej toponimu Dalanów ${ }^{44}$ (pow. kępiński, woj. wielkopolskie), reinterpretującej go jako zrost słów dola i nów, potwierdzać mają fakty dotyczące występowania motywu nowiu księżyca w malarstwie, rzeźbie, na pieczęciach i herbach, por.:

Dalanów (dawniej Dola nów) - wyraz ten składa się z dwóch słów. Pierwsze to dola a więc los człowieka drugi to nów i chodzi tu o Księżyc. Bardzo często na obrazach, rzeźbach artyści przedstawiali los człowieka w postaci księżyca w nowiu. Przykładem może być Obraz Matki Boskiej Łaskawej zwanej dziś Koszycką. Księżyc w nowiu przedstawiony jest również w obrazie Matki Boskiej Ostrobramskiej.

Księżycem w nowiu jako pieczęciom [tak!] posługiwał się Henryk Brodaty (opiekun Bolesława Wstydliwego) a potem jego syn Henryk Pobożny. Symbol ten został upamiętniony przez ród Tarnowskich w herbie Leliwa, znalazł się w herbie Śląska, również w herbie miasta Wrocławia (Dalanów).

Etymologie ludowe polskich toponimów są rezultatem potocznej świadomości językowej, ale ponieważ w potocznej świadomości językowej tkwi szacunek dla wiedzy naukowej, etymologie nienaukowe często wykorzystują elementy tej wiedzy. Niedostatek wiedzy onomastycznej u twórców takich pseudoetymologii nie pozwala wprawdzie zaliczyć rezultatów ich reinterpretacji etymologicznych do etymologii onomastycznych, ale przystępność i rosnąca dostępność innych rodzajów wiedzy naukowej powoduje, że rola różnych ustaleń naukowych w budowaniu pseudoetymologii stale wzrasta.

\section{Bibliografia}

Ankieta 1 - ankieta w I LO w Łomży.

Ankieta 2 - ankieta w II LO w Łomży.

Babik Z., 2001, Najstarsza warstwa nazewnicza na ziemiach polskich, Kraków.

Breza E. 1999: Kościerzyna, w: H. Górnowicz, Z. Brocki (red.), Nazwy miast Pomorza Gdańskiego, wyd. 2. popr. i poszerz., red. E. Breza i J. Treder, Gdańsk, s. 129-134.

Brodzicki C., 1999, Ziemia łomżyńska do 1529 roku, Warszawa.

Brückner A., 1974, Stownik etymologiczny języka polskiego, Warszawa.

Brzozowska M., 2009, Etymologia a konotacja słowa. Studia semantyczne, Lublin.

Chorzele - http://www.kurpiankawwielkimswiecie.pl/2016/08/maa-ojczyzna-co-kryje-sie-w-nazwach.html [data dostępu: 10.04.2018].

Chrzelice - http://www.chrzelice.pl/nazwa_wsi.php [data dostępu 2.06.2011].

Cienkowski W., 1972, Teoria etymologii ludowej, Warszawa.

Cieszowa - http://www.kirkuty.xip.pl/cieszowa.htm [data dostępu: 22.01.2013].

${ }^{44}$ W Nazwach miejscowych Polski nie ma hasła Dalanów, znajdziemy tu natomiast nazwę Dalanowo (pow. płoński), którą U. Bijak objaśnia jako derywat z sufiksem -ów od nazwy osobowej Dalan, utworzonej od imion typu Dalebor, Dalemir (NMP 1997: II, 257). 
Cyców 1 - https://kielce.onet.pl/wachock-pcim-cycow-hujowa-gorka-i-inne/0kkz7 [data dostępu: 10.04.2018].

Cyców 2 - http://gdkcycow.pl/component/content/article/9-uncategorised/469-punkt-informacji-turystycznej-w-cycowie [data dostępu: 10.04.2018].

Czelakowska A., 2017, Wiedza kulturowa a opis leksykograficzny w jednojęzycznym słowniku języka polskiego, „Lingvaria. Półrocznik Wydziału Polonistyki Uniwersytetu Jagiellońskiego” XII, nr 2 (24), s. 19-35.

Dalanów - http://www.kurier.iap.pl/zdanie/20110506sladami/1druk.php [data dostępu: 10.04.2018].

Gierowski W., 1961, Jak powstały Kielce, „Słowo Ludu”, nr 70, dodatek „Magazyn Niedzielny”, 4-5. 03. 1961, s. 6-7.

Gloger Z., 1903, Dolinami rzek. Opisy podróży wzdluż Niemna, Wisły, Bugu i Biebrzy przez ..., Warszawa.

Gostków - http://www.parki.org.pl/parki-dworskie-i-przypalacowe/klasycystyczny-zespol-palacowo---parkowy-w-go [data dostępu: 13.04.2018].

Guiraud P., 1976, Semantyka, Warszawa

Halicka I., 1976, Nazwy miejscowe środkowej i zachodniej Białostocczyzny dzierżawcze, patronimiczne i rodzinne, Warszawa.

Halicka I., 1978, Nazwy miejscowe środkowej i zachodniej Białostocczyzny topograficzne i kulturowe, Warszawa.

Jastarnia - http://www.apartamentyzdrojowy.pl/index.php?option=com_content\&view=article\&id=1\&Itemid=2 [data dostępu: 10.04.2018].

Jędruszuk W., Łosice, http://www.rtg.siedlce.pl/?str=kacik_kul_tur\&r=losice [data dostępu: 13.04.2018].

Kaleta Z., 1998, Teoria nazw własnych, w: Polskie nazwy własne. Encyklopedia, red. E. Rzetelska-Feleszko, Warszawa-Kraków, s. 15-36.

Kania S., Tokarski J., 1984, Zarys leksykologii i leksykografii polskiej, Warszawa.

Karaś H., http://www.dialektologia.uw.edu.pl/index.php?11=leksykon\&lid=566 [data dostępu: 10.04.2018].

Kolberg O., 1964, Mazowsze. Obraz etnograficzny, t. IV. Mazowsze Stare. Mazury. Kurpie, Kraków 1888, reedycja fotooffsetowa, Warszawa, w: O. Kolberg, Dzieła wszystkie, t. 27, s. 30.

Konojad 1 - http://monety.banknoty.pl/kalisz/okolgrw.htm [data dostępu: 10.04.2018].

Konojad 2 - https://pl.wikipedia.org/wiki/Konojad [data dostępu: 14.04.2018].

Kostkiewiczowa T. [tk], 1988, Etymologia ludowa, w: Słownik terminów literackich, red. J. Sławiński, wyd. 2. poszerz. i popr., Wrocław-Warszawa-Kraków-Gdańsk-Łódź.

Kowal - http://mlewandowski.pl/gniazdo_kowal.html [data dostępu: 13.04.2018].

Lelis - www.forum.weneda.net/viewtopic.php?f=3\&t=9\&view=next [data dostępu: 13.04.2018].

Malec M., 2003, Stownik etymologiczny nazw geograficznych Polski, Warszawa.

Michow E., 2008, Legenda Kielc zamknięta w nazwie. Studium etymologiczne i kulturowe, Kielce.

Modzele - https://pl.wikipedia.org/wiki/Stare_Modzele [data dostępu: 8.04.2018].

NMP - Nazwy miejscowe Polski. Historia - pochodzenie - zmiany, red. K. Rymut, od t. VIII red. K. Rymut i B. Czopek-Kopciuch, od t. X red. K. Rymut, B. Czopek-Kopciuch i U. Bijak, t. I 1996 , t. II -1997 , t. III -1999 , t. IV -2001 , t. V -2003 , t. VI -2005 , t. VII -2007 , t. VIII -2009 , t. IX -2013 , t. X - 2015, t. XI - 2015, t. XII - 2015, t. XIII - 2016, Kraków.

PSWP - Praktyczny słownik współczesnej polszczyzny, red. H. Zgółkowa, t. 1-50, Poznań 1994-2005.

Paluszak-Bronka A., Czachorowska M., 1998, Etymologia naukowa a ludowa nazw dzielnic Bydgoszczy, w: Najnowsze przemiany nazewnicze, red E. Jakus-Borkowa i K. Nowik, Warszawa, s. 401-413.

Pazdur J., 1967, Dzieje Kielc, do 1863 r., Wrocław.

Piekary - http://piekaryslaskie.com.pl/p,s,434571.html [data dostępu: 10.04.2018]. 
Płock - http://www.historycy.org/index.php?s=6428a6941532dad6cb003a761e4a4406\&showtopic $=8259 \& \mathrm{st}=0$ [data dostępu: 10.04.2018].

Pyzdry - http://alehistoria.blox.pl/2009/07/PYZDRY.html [data dostępu: 10.04.2018].

Radziejów - http://www.umradziejow.pl/?a=40 [data dostępu: 10.04.2018].

Resko - http://www.resko.pl/content.php?mod=kontakt\&lang=pl [data dostępu: 10.04.2018].

Rogowska-Cybulska E., 2012, O etymologiach ludowych nazw miejscowości w gminie Wizna, w: Polszczyzna regionalna. Polszczyzna pólnocno-wschodniego Mazowsza, cz. VII, red. H. Sędziak i D. Czyż, Ostrołęka, s. 231-248.

Rogowska-Cybulska E., 2013, O etymologii ludowej nazw miejscowych jako zjawisku skalarnym, w: Cum reverentia, gratia, amicitia... Księga jubileuszowa dedykowana Profesorowi Bogdanowi Walczakowi, red. J. Migdał i A. Piotrowska-Wojaczyk, Poznań, t. III, s. 77-85.

Rogowska-Cybulska E., 2014, Obraz dawnej architektury miejskiej w etymologiach ludowych nazw miast, w: Miasto - przestrzeń zróżnicowana językowo, kulturowo i społecznie, t. 5, red. M. Święcicka i M. Peplińska-Narloch, Bydgoszcz, s. 123-139.

Rogowska-Cybulska E., 2015a, Motyw wierzeń pogańskich w etymologiach ludowych polskich toponimów, „Język - Szkoła - Religia” 10, nr 3, s. 7-21.

Rogowska-Cybulska E., 2015b, O sposobach tworzenia nazw miejscowości w świetle etymologii ludowej, „LingVaria” 19, s. 271-283.

Rogowska-Cybulska E., 2016a, „Nazwy przecież musza być. Nie da się jeździć w czystej przestrzeni...”. Motyw transportu i komunikacji w etymologiach ludowych polskich toponimów, w: Miasto - przestrzeń zróżnicowana językowo, kulturowo i społecznie, t. 6, red. M. Święcicka i M. Peplińska, Bydgoszcz, s. 75-95.

Rogowska-Cybulska E., 2016b, O motywie chrztu w etymologiach ludowych polskich toponimów, „Język - Szkoła - Religia” XI/2, s. 35-45.

Rogowska-Cybulska E., 2017, O motywacji topograficznej w etymologiach ludowych polskich toponimów, „Poradnik Językowy”, nr 4, s. 51-62.

Rospond S. 1984, Stownik etymologiczny miast $i$ gmin PRL, Wrocław-Warszawa-Kraków-GdańskŁódź.

Rymut K., 1987, Nazwy miast Polski, Wrocław-Warszawa-Kraków-Gdańsk-Łódź.

Sambory - http://www.jaswily.iap.pl/?id=706\&location=f\&msg=1 [data dostępu: 10.04.2018].

Samborze 1 - https://pl.wikipedia.org/wiki/Samborze [data dostępu: 10.04.2018].

Samborze 2 - http://kajakix.republika.pl/biebrza.htm [data dostępu: 10.04.2018].

Sędziak H., 2009, Nazwy wsi drobnoszlacheckich w Łomżyńskiem, Łomża.

Sstp - Stownik staropolski, red. S. Urbańczyk, t. I-XI, Kraków 1953-2002.

Strzegom - http://pl.wikipedia.org/wiki/Strzegom [data dostępu: 1.01.2016].

SW - J. Karłowicz, A. Kryński i W. Niedźwiedzki, Słownik języka polskiego, t. I-VIII, Warszawa 1900-1927.

Swil - Słownik języka polskiego, wypracowany przez A. Zdanowicza i in., t. I-II, Wilno 1861.

Toszek - http://www.mjfoto.pl/miejsca/fotograf_toszek/ [data dostępu: 10.04.2018].

Warszawa - http://www.historycy.org/index.php? showtopic $=8259 \&$ st $=105$ [data dostępu: 10.04.2018].

Wiślica - http://pl.wikipedia.org/wiki/Wi\%C5\%9Blica [data dostępu: 22.01.2013].

Wiśniewski J., 1974, Ród Wagów, w: Rodzina Wagów w kulturze polskiej, praca zbiorowa red. W. Grębecka, Warszawa, s. 7-15.

Taszycki W., 1946, Słowiańskie nazwy miejscowe (ustalenie podziatu), Kraków.

WSJP - Wielki słownik języka polskiego, red. P. Żmigrodzki: wsjp.pl [data dostępu: 10.04.2018].

Zierhoffer K., 1957, Nazwy miejscowe pótnocnego Mazowsza, Wrocław.

Zierhofferowa Z., Zierhoffer K., 2012, Etymologie ludowe, ich funkcja i struktura, „Onomastica” LVI, s. 15-23. 
Zierhofferowa Z., Zierhoffer K., 2013, Etymologie ludowe toponimów - historycznie i współcześnie, w: Trwanie w języku... Pamięci Profesor Moniki Gruchmanowej w 10. rocznicę Jej śmierci, red. A. Piotrowicz, M. Witaszek-Samborska, Poznań, s. 49-56.

\section{EWA ROGOWSKA-CYBULSKA}

\section{Elements of academic knowledge of folk (non-academic) origins of names of Polish locations}

\section{Sumnary}

The goal of this article is to present the fundamental types of such pseudo-origins. The collated examples of approximately a thousand of association origins of Polish names of locations, excerpted from various printed and online texts, written questionnaires and oral interviews, indicate three types of non-academic origin employing elements of academic knowledge.

Keywords: folk origin, onomastics, Polish names of locations 